\title{
Repair CNS Injury by Combination of Olfactory Ensheathing Cells with Biomaterials
}

\author{
D Li , A Ibrahim ${ }^{1,2}$, K Minkelyte ${ }^{1}$, Modinat Olushanu ${ }^{1}$, B Steven ${ }^{3}$, P Tabakow ${ }^{4}$ and Y Li ${ }^{1 *}$ \\ ${ }^{1}$ Department of Brain Repair and Rehabilitation, UCL Institute of Neurology, UK \\ ${ }^{2}$ Barking, Havering and Redbridge University Hospitals, $U K$ \\ ${ }^{3}$ School of Science and Technology, Nottingham Trent University, UK \\ ${ }^{4}$ Department of Neurosurgery, Wroclaw Medical University, Poland
}

*Corresponding author: Professor Ying Li, Spinal Repair Unit, Department of Brain Repair and Rehabilitation UCL Institute of Neurology, Queen Square, London WC1N 3BG, UK.

To Cite This Article: D Li, A Ibrahim, K Minkelyte, Modinat Olushanu, B Steven. Repair CNS Injury by Combination of Olfactory Ensheathing Cells with Biomaterials. Am J Biomed Sci \& Res. 2019 - 6(2). AJBSR.MS.ID.001015. DOI: 10.34297/AJBSR.2019.06.001015.

Received: 眥 November 8, 2019; Published: 眥 November 14, 2019

\section{Introduction}

Despite advances in understanding the failure of CNS to regenerate and technological improvements in post-injury rehabilitation, there is still no effective treatment for devastating injuries to the spinal cord. Cell transplantation has demonstrated to be one of the most promising therapeutic strategies to restore neurological functions after spinal cord injury (SCI). Olfactory ensheathing cells (OECs) are amongst the leading candidates in the field. OECs are specialized glial cells that can be obtained from either olfactory bulb or olfactory mucosa tissue. OECs are effective in anatomical repair and functional restoration in experimental injury models and in clinical application [1-12].

However, in the context of much larger human spinal cord compared to experimental animal models the number of OECs derived from biopsied olfactory tissue is insufficient to cover the typically larger damaged area. This deficiency of OEC numbers becomes even more a challenge when considering use of autologous tissue for transplantation. Use of biomaterials is one strategy to expand the transplant size by seeding OECs with a biomaterial scaffold. This form of cell-biomaterial construct would enable the small number of cells to cover a large injury area. Studies in neural regeneration have shown positive outcomes by using different biomaterials. For example, Shen et al. [12] studied the guidance of OEC growth and migration on electrospun silk fibroin scaffolds; Roloff et al. [13] used the spider silk as guiding biomaterial for human model neurons; Madigan et al. [14] used polymer scaffolds to induce axonal regeneration following spinal cord injury; Olson's group used biodegradable polymer scaffolds to load neural stem cells and Schwann cells to support axonal regeneration in the transected spinal cord and Xie's team showed the differentiation of embryonic stem cells seeded on electrospun nanofibers into neural lineages [12-20].

Our team has fabricated a cellular scaffold by combining cultured human bulbar OECs (hOECs) with collagen [7]. We have also explored growing rat bulbar OECs on nanofibers as a method to enable limited numbers of cells to bridge extensive injuries [19].

\section{Olfactory Ensheathing Cells/Collagen Scaffold}

We previously transplanted OECs to the injury sites with two methods - microinjection of single cell suspension and grafting cell aggregates formed with the cells' own extracellular matrix. When using injection of cell suspension, the transplanted cells were difficult to be retained at the target site; using cell aggregates was able to retain the cells in place but required many cells to generate a well-formed aggregate [21,22]. In one of our recent studies we mixed hOECs at a specific density with collagen distributing the cells evenly throughout the gel to form a contiguous meshwork (Figure 1B). Compared to our previous OEC transplantation method using the cell aggregate, the size of the transplant created in this way increases by at least eight times. The hOEC-collagen scaffold could be trimmed into desired shapes, for example small strips, (Figure 1A) and easily transplanted into the injury areas where they remained in place affixed with fibrin glue. We transplanted the hOECs-collagen scaffold in an experimental model of a unilateral transection of four dorsal roots (C6-T1). Cyclosporine was administered daily to prevent immune rejection. Forelimb proprioception was assessed weekly in a vertical climb task. Results showed that half of the rats receiving the transplants gained functional improvement. 


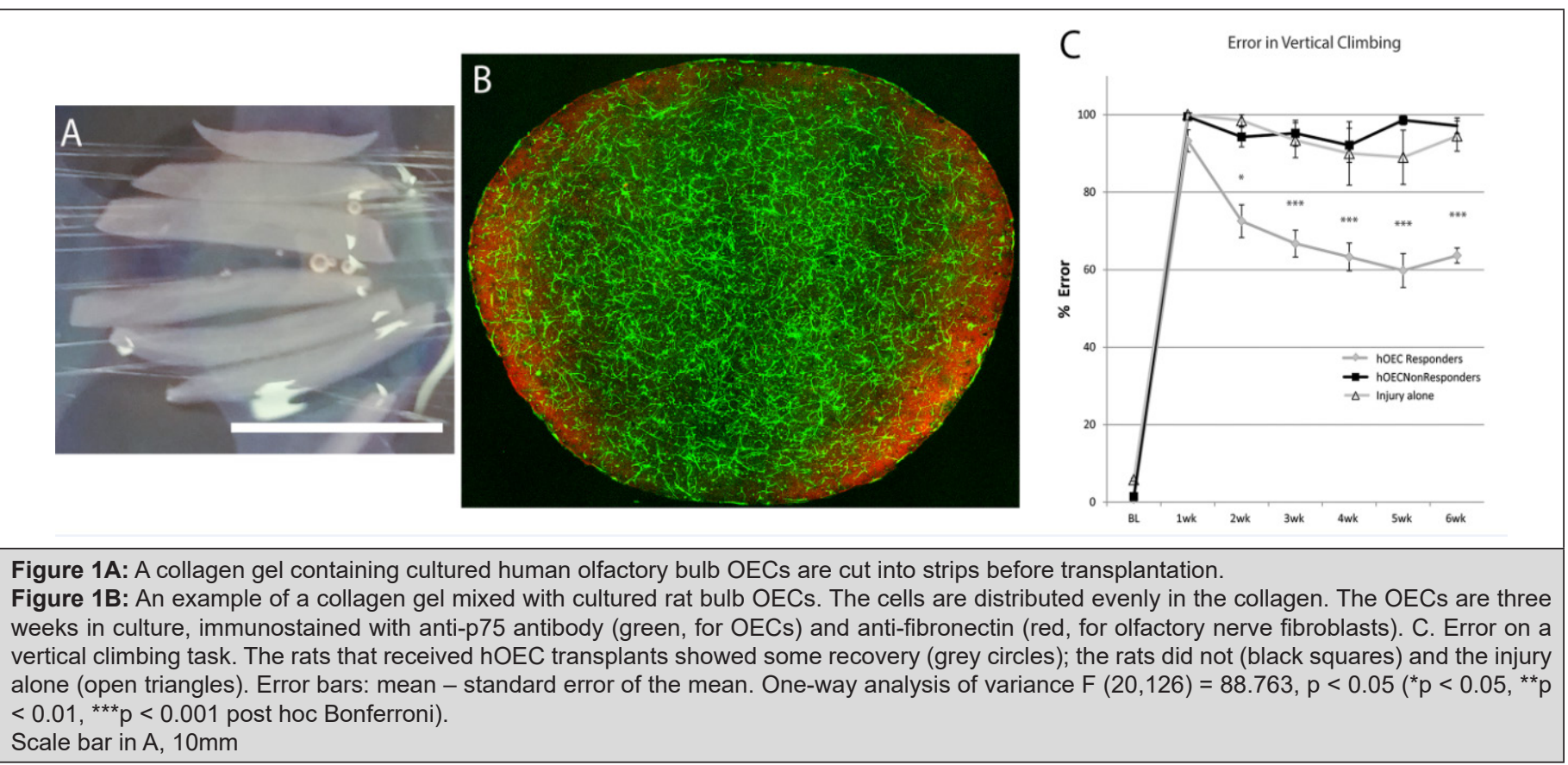

\section{Olfactory Ensheathing Cells/Nanofibers}
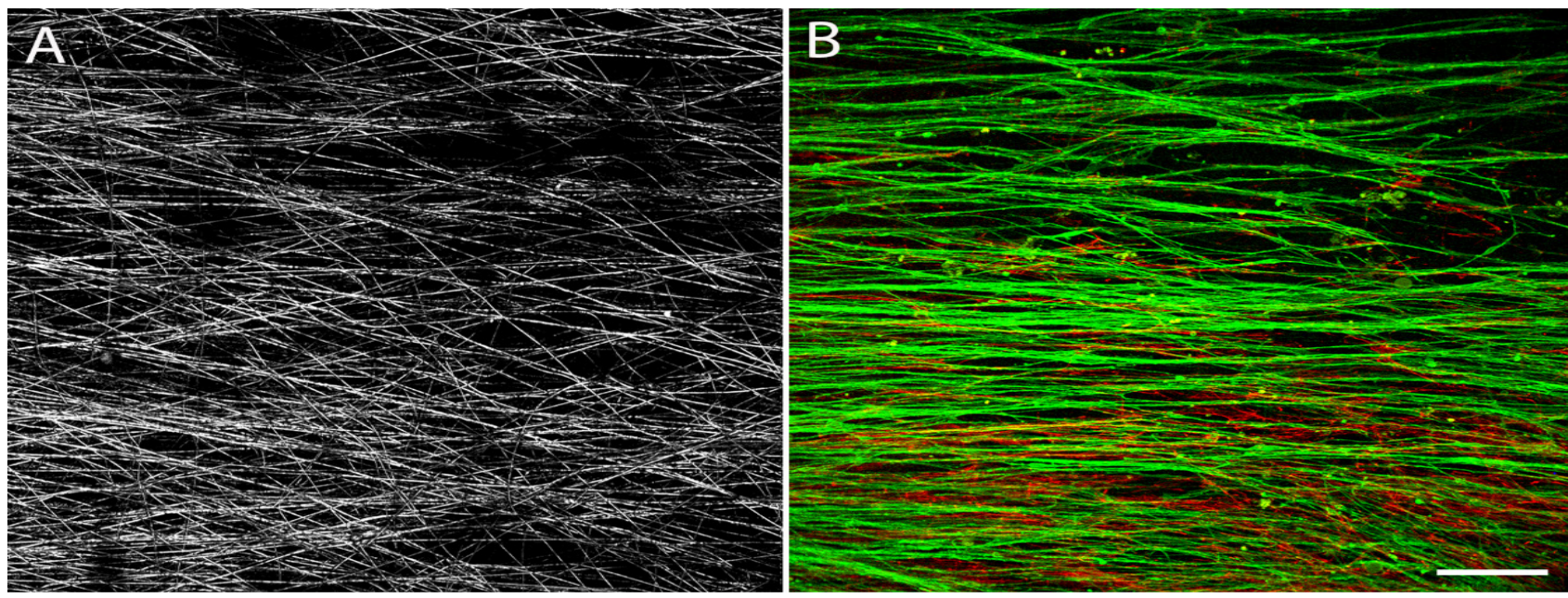

Figure 2A: Confocal image showing meshwork of nanocomposite electrospun PLGA nanofibers.

Figure 2B: Cultured rat OECs grow on the nanofibers. Double immunostaining of p75 (green, for OECs) and fibronectin (red, for olfactory nerve fibroblasts). The OECs elongate along the direction of the nanofibers and form a contiguous cellular meshwork. Confocal image; scale bar: $200 \mu \mathrm{m}$.

Studies have shown that nanotechnology has made it possible to fabricate biodegradable structures at a controlled submicron scale, as mentioned in the introduction. Our team has published data of growing OECs on a nanofiber scaffold created by electrospinning of poly lactic-co-glycolic acid (PLGA, an FDA approved biodegradable material). We examined the compatibility of rat OECs growing on different diameters of such fibers. We showed that the OECs survived well on the nanofibers. When these fibers are pre-aligned (Figure 2A) the OECs seeded on them showed a tendency to lie in the same orientation of the fibers extending their processes along the direction of the fibers bi-directionally and forming a unidirectional meshwork (Figure 2B). We are in progress of testing this cellular construct in our experimental models. The OEC-nanofiber construct is fragile to handle. Our co-workers are designing devices for this construct to be easily handled for future clinical application.

\section{Summary}

Combination of OECs with biomaterials such as collagen increases the transplant size significantly without affecting the neural repair capacity of OECs. This improves the prospect of transplantation of OECs to bridge a larger surface area of injured spinal cord such as those seeing in human contusion injuries. Elongation of OECs guided nanofibers providing directional pathways may be more efficient in promoting regeneration of nerve fibers in spinal cord injury. 


\section{Acknowledgements}

The work was supported by funds from the UK Stem Cell Foundation and the Nicholls Spinal Injury Foundation. We thank Dr Wojciech Fortuna for his collaboration.

\section{References}

1. Plant GW, Harvey AR, Leaver SG, Lee SV (2011) Olfactory ensheathing glia: repairing injury to the mammalian visual system. Exp Neurol 229(1): 99-108.

2. Roet KC, Verhaagen J (2014) Understanding the neural repair-promoting properties of olfactory ensheathing cells. Exp Neurol 261: 594-609.

3. Franklin RJ, Gilson JM, Franceschini IA, Barnett SC (1996) Schwann cell-like myelination following transplantation of an olfactory bulbensheathing cell line into areas of demyelination in the adult CNS. Glia 17: 217-224.

4. Kocsis JD, Lankford KL, Sasaki M, Radtke C (2009) Unique in vivo properties of olfactory ensheathing cells that may contribute to neural repair and protection following spinal cord injury. Neurosci Lett 456: 137-142.

5. Ramer LM, Au E, Richter MW, Liu J, Tetzlaff W, et al. (2004) Peripheral olfactory ensheathing cells reduce scar and cavity formation and promote regeneration after spinal cord injury. J Comp Neurol 473: 1-15.

6. Ramon-Cueto A, Nieto-Sampedro M (1994) Regeneration into the spinal cord of transected dorsal root axons is promoted by ensheathing glia transplants. Exp Neurol 127: 232-244.

7. Collins A, Li D, Liadi M, Tabakow P, Fortuna W, et al. (2018) Partial Recovery of Proprioception in Rats with Dorsal Root Injury after Human Olfactory Bulb Cell Transplantation. J Neurotrauma 35(12): 1367-1378.

8. Tabakow P, Raisman G, Fortuna W, Czyz M, Huber J, et al. (2014) Functional regeneration of supraspinal connections in a patient with transected spinal cord following transplantation of bulbar olfactory ensheathing cells with peripheral nerve bridging. Cell Transplant 23(12): 1631-1655.

9. Li Y, Carlstedt T, Berthold CH, Raisman G (2004) Interaction of transplanted olfactory-ensheathing cells and host astrocytic processes provides a bridge for axons to regenerate across the dorsal root entry zone. Exp Neurol 188: 300-308.

10. Li Y, Decherchi P, Raisman G (2003) Transplantation of olfactory ensheathing cells into spinal cord lesions restores breathing and climbing. J Neurosci 23(3): 727-31.
11. Li Y, Field PM, Raisman G (1998) Regeneration of adult rat corticospinal axons induced by transplanted olfactory ensheathing cells. J Neurosci 18(24): 10514-10524.

12. Shen Y, Qian Y, Zhang H, Zuo B, Lu Z, et al. (2010) Guidance of olfactory ensheathing cell growth and migration on electrospun silk fibroin scaffolds. Cell Transplant 19: 147-57

13. Roloff F, Strauss S, Vogt PM, Bicker G, Radtke C (2014) Spider silk as guiding biomaterial for human model neurons. Biomed Res Int 2014: 906819.

14. Madigan NN, McMahon S, O’Brien T, Yaszemski MJ, Windebank AJ (2009) Current tissue engineering and novel therapeutic approaches to axonal regeneration following spinal cord injury using polymer scaffolds. Respir Physiol Neurobiol 169(2): 183-199.

15. Kim K, Yu M, Zong X, Chiu J, Fang D, et al. (2003) Control of degradation rate and hydrophilicity in electrospun non-woven poly(D, L-lactide) nanofiber scaffolds for biomedical applications. Biomaterials 24(27): 4977-4985.

16. Min BM, Lee G, Kim SH, Nam YS, Lee TS, et al. (2004) Electrospinning of silk fibroin nanofibers and its effect on the adhesion and spreading of normal human keratinocytes and fibroblasts in vitro. Biomaterials 25(78): 1289-1297.

17. Venugopal JR, Zhang Y, Ramakrishna S (2006) In vitro culture of human dermal fibroblasts on electrospun polycaprolactone collagen nanofibrous membrane. Artif Organs 30(6): 440-446.

18. Xie J, Willerth SM, Li X, Macewan MR, Rader A, et al. (2009) The differentiation of embryonic stem cells seeded on electrospun nanofibers into neural lineages. Biomaterials 30(3): 354-362.

19. Kueh JL, Li D, Raisman G, Jenkins D, Li Y, et al. (2012) Directionality and bipolarity of olfactory ensheathing cells on electrospun nanofibers. Nanomedicine (Lond) 7(8): 1211-1224.

20. Olson HE, Rooney GE, Gross L, Nesbitt JJ, Galvin KE, et al. (2009) Neural stem cell- and Schwann cell-loaded biodegradable polymer scaffolds support axonal regeneration in the transected spinal cord. Tissue Eng Part A 15(7): 1797-805.

21. Ibrahim AG, Kirkwood PA, Raisman G, Li Y (2009) Restoration of hand function in a rat model of repair of brachial plexus injury. Brain 132(Pt 5): $1268-1276$.

22. Collins A, Li D, McMahon SB, Raisman G, Li Y (2017) Transplantation of Cultured Olfactory Bulb Cells Prevents Abnormal Sensory Responses During Recovery from Dorsal Root Avulsion in the Rat. Cell Transplant 26(5): 913-924. 